\title{
LA FUNCIÓN PARÓDICA DE LAS ESTRATEGIAS METAFICCIONALES. APUNTES SOBRE LA ADAPTACIÓN CINEMATOGRÁFICA DE LA ZARZUELA DOÑA FRANCISQUITA (LADISLAO VAJDA, 1952)*
}

José Antonio Pérez BowIE Universidad de Salamanca

\section{La zarzuela en la pantalla}

La zarzuela es uno de los géneros teatrales por los que se sintió más atraído el cine español durante los primeros cincuenta años de su historia. De modo un tanto inexplicable ${ }^{1}$, ya en la etapa previa al sonoro se filmaron un número considerable de películas basadas en sus libretos: puede decirse que desde sus balbuceos iniciales la cinematografía española se interesó por la zarzuela ofreciendo en principio fragmentos (Aria de Leonor, de la zarzuela El anillo de hierro; Polka de los paraguas, de Luisa Fernanda; Caracolillo, de Certamen Nacional; rodados todos en 1900 ,

"Este trabajo se inscribe en el marco del proyecto de investigación HUM2004-02103 («Teoría y práctica de la adaptación cinematográfica de textos literarios en España:1950-1975») financiado por la Dirección General de Investigación de Ministerio de Educación y Ciencia

1. Probablemente, el interés del público hacia tales filmes radicaba en el reconocimiento de unas tramas perfectamente sabidas, aunque también hay que tener en cuenta, que las proyecciones de cine mudo siempre fueron acompañadas de música ejecutada en la sala, por lo que, en el caso de las adaptaciones de zarzuelas, el pianista o la pequeña orquesta ilustraban la proyección con los números musicales de las mismas. Por otra parte, hay que hacer constar que ya en 1906, Ricardo Baños, por encargo de la productora francesa Gaumont, comenzó a rodar sus versiones de zarzuela acompañadas de la grabación de discos de fonógrafo que luego se escuchaban en la sala como complemento delas imágenes filmadas. 
sin que conste el nombre del director $)^{2}$ y posteriormente argumentos más o menos resumidos como, por ejemplo, El dúo de la Africana (Ricardo Baños, 1906), La Dolores (Fructuoso Gelabert, 1908), El puñao de rosas o La tempranica (ambos de Segundo Chomón, 1910) ${ }^{3}$. En la década de los 20 , ya con una mayor perfección técnica y posibilidades de un metraje más amplio, el género lírico continuó afluyendo a las pantallas de la mano de directores como José Buchs, responsable de adaptaciones como Carceleras (1920), El pobre Valbuena y Doloretes (ambas en 1923). Ese año de 1923, es el más prolífico en este aspecto, pues durante él se adaptan 9 zarzuelas, pero a lo largo de toda la década y hasta la irrupción del sonoro se filmarán un total de 30 , normalmente los títulos que gozaban de mayor popularidad, entre ellos La verbena de la Paloma (José Buchs, 1921), La bruja (Maximiliano Thous, 1923), La Revoltosa (Florián Rey, 1924), La bejarana (Fernández Ardavín, 1926), Gigantes y cabezudos (Florián Rey, 1926), La del soto del Parral (León Artola, 1928) o El rey que rabió (José Buchs, 1929) ${ }^{4}$.

Paradójicamente, la llegada del sonoro supone una disminución de las adaptaciones del género lírico, ya que desde 1931 hasta el final de la guerra civil sólo se filman 13 títulos; las razones de este descenso habrá que explicarlas por la incidencia del conflicto bélico, aunque también por las deficiencias técnicas de la reproducción del sonido en los primeros años de su implantación. Algunas de las zarzuelas que se filman son nuevas versiones de las que ya habían sido llevadas a la pantalla muda como La verbena de la Paloma (Benito Perojo, 1935), Los claveles (Santiago Ontañón, 1935), aunque también se incorporan nuevos títulos como Doña Francisquita (Hans Behrend, 1934), La Dolorosa (Jean Gremillon, 1934), El gato montés (Rosario Pí, 1935), Bohemios (Francisco Elías, 1937) o El rey que rabió (José Buchs, 1937). Tras la guerra civil continúa esa tendencia a la baja, ya que en el periodo 1940-1950 sólo se llevan a la pantalla seis zarzuelas, entre ellas una nueva versión de La Revoltosa (José Díaz Morales, 1949) y otras como La alegría de la huerta (Ramón Quadreny,

2. Los trece títulos producidos ese año son todos, curiosamente, fragmentos de zarzuelas o de óperas, como se puede comprobar en Pascual Cebollada y Luis Rubio Gil: Enciclopedia del cine español. Cronologia,Barcelona: Ediciones del Serbal, 1996, p.20.

3. Véase Cebollada y Rubio Gil, op. cit.

4. Para una información más detallada, véase J.T. Cánovas Belchi «La legitimidad artística de un nuevo espectáculo. Fuentes literarias del cine mudo español» en Carlos F. Heredero (coord.): $\mathrm{La}$ imprenta dinámica. La literatura española en el cine español, $\mathrm{n}^{\circ}$ monográfico de Cuadernos de la Academia, 11-12, 2002, pp. 21-38. 
1940) o La tempestad (Javier de Rivera, 1944) ${ }^{5}$. Y si nos atenemos a la década de los 50, en que Ladislao Vajda rueda su versión de Doña Francisquita, se constata que es la de menor presencia del género lírico en la pantalla, ya que, aparte del filme de Vajda, sólo se puede hablar de otra adaptación: La reina mora (Raúl Alfonso, 1954); aunque si abarcamos también el año 1960 pueden añadirse otros dos títulos Alma aragonesa (José Ochoa) y una nueva versión de Los claveles dirigida por Miguel Lluch.

El definitiva, el momento en que Ladislao Vajda se dispone a rodar su versión de la zarzuela de Amadeo Vives es el punto más bajo de un proceso de alejamiento del género por parte de la industria cinematográfica española (y, lógicamente también, por parte de los públicos a los que nutría), hecho que nos puede proporcionar la clave para entender el experimento rupturista del director húngaro; especialmente si se tiene en cuenta, el carácter meramente ilustrativo de todas las adaptaciones de zarzuelas precedentes (tanto en el periodo mudo como en el sonoro) atentas tan sólo a poner en imágenes con un exacerbado sentido de la fidelidad las historias que contaban los libretos y, obviamente, a servir de soporte a la partitura ${ }^{6}$.

Cabe, no obstante, referirse a determinadas llamadas que, desde órganos portavoces «oficiosos» del poder franquista, se hacen en las décadas de los 40 y en la de los 50 a favor de una rehabilitación de la zarzuela por parte del cine nacional; tales llamadas se inscriben dentro del debate en torno a la creación de un cine genuinamente español, en el que se buscaban las líneas que había de seguir nuestra industria cinematográfica para superar los tópicos degradantes que transmitían productos como el género seudofolklórico (la denostada «españolada») y encontrar la fórmula para exportar la imagen de la «nueva España» surgida tras la victoria al resto del mundo. Citemos como muestra de esta campaña un artículo publicado en Radiocinema por Francisco Casares, quien parte del éxito obtenido por la reciente versión cinematográfica de La Revoltosa (1949), que, de la mano de Díaz Morales «se ha llevado al cine con el atuendo, con la

5. VéaseLuis Fernández Colorado: «Voces y sombras en una república de las letras. Escritores y cinema en España (1931-1939)» y Román Gubern: «Mirando hacia otro lado. Literatura y cine en los años 40», ambos en el citado libro coordinado por Carlos F. Heredero, pp. 38-55 y 57-76 respectivamente.

6. Ese criterio de extrema fidelidad a la letra del texto es el que continuaron manejando las pocas adaptaciones que se rodarían con posterioridad: las dos de La Revoltosa (José Díaz Morales en 1963 y Juan de Orduña en 1969) y la de La verbena de la Paloma, dirigida por José Luis Sáenz de Heredia en 1963. 
grandiosidad que merecía», para reivindicar la zarzuela como fuente de argumentos para la pantalla, por ser la expresión más genuina del folklore español:

Estamos presenciando, todos los días, con sus enormes falsedades y deformaciones, el auge de ese género en boga que se ha apropiado del vocablo folklore. Es inútil que se luche para demostrar que el folklore es otra cosa, y no se debe admitir como su expresión genuina y veraz esa falsificación burda de «jipíos» y de estampas de escasa calidad. La verdadera manifestación folklórica está en las zarzuelas, que recogen ambientes de las distintas provincias, con sus canciones populares y sus costumbres y trajes. $Y$ como el cine es el más poderoso instrumento de divulgación, si se quiere, de verdad y por el buen camino, que nuestro folklore sedifunda -incluso que se destruya todo lo falso y de mal gusto- habrá que convenir que la fórmula eficaz, la única, es llevar a los lienzos todo ese conjunto de obras que recogen las esencia de los trazos y el carácter de las regiones españolas?

Como se puede comprobar, tal tipo de recomendaciones no surtió ningún efecto: la zarzuela, al menos tal como se había llevado hasta entonces a la pantalla, había dejado de interesar a los espectadores $y$, en consecuencia, a los productores. Esa deserción del público, que venía afectando también a las manifestaciones teatrales del género, implicaba, sin duda, una cierta «desacralización» de los textos lo que hacía posible un acercamiento irreverente a los mismos. En el caso que nos ocupa, la condición de extranjero del realizador (un húngaro recién afincado en España) potenciaba la mirada «extrañante» y proporcionaba, por tanto, el grado de distancia necesario que su acercamiento a Doña Francisquita, alejado de los cánones al uso y de sus exigencias de fidelidad a los textos, requería.

\section{La Doña Francisquita cinematográfica de Ladislao Vajda}

\subsection{El texto de partida}

Doña Francisquita es una de las últimas grandes zarzuelas, cuyo estreno en el teatro Apolo de Madrid (17-X-1923), significó un intento de revitalización del género, sumido en una importante crisis a causa de las numerosas variantes epigonales que lo estaban minando ${ }^{8}$. El compositor

7. «Nuestro género lírico y el cine nacional», Radiocinema, n 171, sept. 1950

8. Vid. Miguel Roa: «Introducción», en Amadeo Vives: Doña Francisquita, Madrid: Instituto Complutense de Ciencias Musicales, 2005 (ed. de Guillermo Roca), especialmente pp. XII-XIII. 
había contribuido con dos piezas anteriores a ese objetivo (Maruxa en 1914 y Bohemios en 1920) que fueron éxitos clamorosos y significaron, al igual que la que nos ocupa, la recuperación del romanticismo sentimentalista presente en todas las piezas canónicas del género.

La trama del libreto, encargado por el compositor Amadeo Vives a Guillermo Fernández Shaw y Federico Romero, se atiene en lo esencial y con bastante fidelidad a la acción de la comedia de enredo de Lope de Vega La discreta enamorada, que le sirvió de modelo. En el acto primero, que transcurre en una plaza donde se encuentra la pastelería de doña Francisquita y su madre doña Francisca, se nos presenta a la joven que sufre de amor por Fernando, quien, a su vez, sólo tiene ojos para Aurora, aunque su amigo Cardona intenta disuadirlo de que renuncie a ésta por Francisquita. A su vez, el viudo don Matías, padre de Fernando, pide la mano de su hija a doña Francisca, ante la desilusión de ésta, quien pensaba que era ella el objeto de interés del viejo. La trama se complica cuando Francisquita finge aceptar la proposición de don Matías para dar celos a Fernando (indisponiendo con ello a padre e hijo) y éste, a su vez, piensa en utilizar a Francisquita para encelar a Aurora. La acción del segundo acto sucede en una explanada, próxima a un merendero, donde se celebra una romería; se suceden diversas escenas en las que continúa el juego de los protagonistas, avivado por Cardona, el confidente de Fernando: éste da celos a Aurora con Francisquita, pero también con el propio Cardona, que se ha disfrazado de mujer; don Matías, azuzado por Francisquita, pretende que su hijo se aleje de Madrid; Francisquita finge un desmayo para caer en brazos de Fernando y, a la vez, impedir que éste responda al desafío que Aurora hace a los hombres presentes de bailar con ella logrando que sea don Matías el que lo haga, a costa de tener que pelear con Lorenzo, el enamorado de Aurora. En el primer cuadro del acto tercero, cuya acción se sitúa ante la puerta de la casa de don Matías, Francisquita sigue utilizando a éste para provocar los celos de Fernando: le dice que no puede ir al baile de Cuchilleros porque Fernando, la ha amenazado por carta con organizarle allí una escena; consigue con ello que don Matías riña con su hijo, quien a la vez se da cuenta de las sutilezas del juego de Francisquita. Cardona, por su parte, manipula para distanciar a Aurora y a Fernando y provoca los celos del enamorado de ésta, Lorenzo, quien decide ir al baile para desafiar allí a Fernando. En el segundo cuadro del acto tercero (el escenario es ahora el patio de la corrrala donde tiene lugar el baile) y ante el alivio de Lorenzo, se produce la ruptura entre Aurora y Fernando, quien se siente atraído de modo definitivo por Francisquita. Pero aún se produce una nueva complicación, pues, para evitar la ira de su padre, Fernando finge que el objeto de su pasión es doña Francisca, cosa que ésta parece 
creer; Aurora interviene despechada acusando a Fernando de mujeriego y tratando de impedir el compromiso; finalmente, don Matías comprende lo absurdo de la situación y accede a la petición de los jóvenes de que les permita casarse. La trama, como exige el género lírico, se convierte en pretexto para la inserción de diversos números musicales, tanto los solos, dúos, tercetos o cuartetos interpretados por los personajes principales («El pañuelito se le cayó», «Peno por un hombre, madre / que no me quiere», la «Canción del ruiseñor», la romanza «Por el humo se sabe donde está el fuego», la «Canción del Marabú») como los de carácter coral: los pregones iniciales del lañador, la buhonera y el aguador, la «Canción de la juventud» entonada por los estudiantes en el acto primero, la intervención de la Cofradía de la bulla, en el acto segundo, las seguidillas al final de este acto en las que participan todos los personajes, etcétera.

\subsection{La adaptación cinematográfica del texto}

Como he adelantado, la lectura que Ladislao Vajda propone sobre la citada zarzuela se caracteriza por su propósito decididamente rupturista que le lleva a una trasgresión sistemática de los modelos de adaptación vigentes, no sólo los de la tradición del cine musical sino de todos los que habían dictado hasta entonces los acercamientos de nuestra cinematografía a los textos literarios. Carlos F. Heredero, refiriéndose al cine español de la posguerra civil, comenta a este respecto la renuncia de los realizadores a «edificar un discurso autónomo a partir de las obras originales utilizadas» y por consiguiente su tendencia a «fotografiar los argumentos sin extraer de su interior una lectura independiente y operativa capaz de elevarlos por encima de las páginas a las que se someten ${ }^{9}$. Esa lectura independiente es precisamente la que va a llevar a cabo Vajda en su adaptación de Doña Francisquita, enfrentándose no sólo a un género cinematográfico de rígida codificación y evolución casi nula en nuestras pantallas, sino también a un género teatral enormemente conservador y asociado a la más rancias tradiciones patrias.

El camino elegido para llevar a cabo una operación semejante fue el de la ironía, mediante la cual anula la carga de sentimentalismo romántico de la peripecia original, deshumaniza ( $y$, en algún caso, degrada) a los personajes y somete toda la historia a la mirada distanciada de un observador curioso pero muy ajeno a los modos y modas que gobernaban el

9. En Las huellas del tiempo. Cine español 1950-1961, Madrid-Valencia: Filmoteca NacionalFilmoteca de la Generalitat Valenciana, 1993, p. 164. 
universo de aquélla. Y el cauce por el que opta para verter esa ironía es un arriesgado planteamiento metaficcional mediante el que «des-construye» totalmente la historia base para proceder a una nueva ordenación de todos sus elementos; $y$, a la vez, la somete, a una narración "problematizada» mediante la interferencia sistemática entre el plano de la ficción (la historia de la Francisquita protagonista de la zarzuela) y el de la «realidad» (la peripecia de la Francisquita protagonista del filme, quien establece paralelismos entre los avatares de aquélla y los de su propia existencia, la cual trata, además, de planificar siguiendo las directrices del libreto de la zarzuela).

Procedamos, para mayor claridad, a fragmentar en secuencias el filme de Vajda:

Títulos de crédito sobre grabados en tono sepia que representan lugares del Madrid antiguo.

Sec. 1. Plaza. La gente se para al oír una voz femenina cantando. Interior: Salón en la academia de Lambertini: doña Francisquita (Fr.), junto a unos jóvenes, ensaya la zarzuela Doña Francisquita, dirigida por el maestro.

Sec. 2. Espacio irreal.Fr., con peluca y traje blanco lujoso, canta apoyada en un piano que parece flotar; por una calle escalonada baja cantando Fernando (F.) y se acerca.

Sec. 3. Salón de la academia. Fr. termina de cantar y Lambertini la felicita.

Sec. 4. Floristería. F. escribe una nota que la florista coloca en un ramo de flores.

Sec. 5. Interior del teatro de la Cruz. Un botones, con un ramo de flores, se abre paso hasta la puerta de un camerino; la puerta se entreabre y entrega el ramo; al volverse se lo arrojan a la cabeza. Se cruza con el representante artístico de Aurora, Lorenzo, quien entra en el camerino.

Sec. 6. Camerino. Aurora grita a su doncella; siente celos porque otra mujer parece interesarse por F. Lorenzo intenta calmarla; ella termina de vestirse y despide a Lorenzo enfurecida.

Sec. 7. Salón de esgrima. F. se bate con otro espadachín. Entra Cardona, quien le aconseja desistir de su amor por Aurora.

Sec. 8. Plaza. Fr. y una amiga esperan el tranvía. F. y Cardona se sientan en una terraza; Fr. y la amiga se sientan en una mesa próxima. Cardona comenta a F. que Fr. es la mujer que pretende su padre, don Matías. Fr. Mira a F. con ojos soñadores. Se alternan imágenes de las conversaciones en ambas mesas.

Sec. 9. Exterior de la confitería «El buen gusto»; llega Cardona y entra. Interior. Fr., al piano, canta acompañada por los operarios. Luego ensa- 
ya el diálogo con Pepe. Canta de nuevo y Cardona aplaude. La madre la apresura, pues d. Matías espera para llevarlas al teatro.

Sec. 10. Calle. D. Matías espera en un coche de caballos; Fr. y su madre suben.

Sec. 11. Teatro la Cruz. En el escenario, Aurora canta «El marabú». F. la contempla desde un palco. Entran d. Matías y sus dos acompañantes y se sientan en el patio de butacas. En el escenario, Aurora baila unas seguidillas acompañada de un coro de mujeres. F. se levanta y sale; Fr. sale tras él.

Sec. 12. Pasillo. Fr. deja caer el pañuelo delante de F., quien lo recoge; pero, nerviosa, es incapaz de aprovechar la situación. F. se marcha con el pañuelo; llega Cardona y la consuela.

$\mathrm{Sec}$.13. Camerino. Aurora discute con F., quien le dice que sus celos son fingidos; F. sale enfadado. A la puerta del camerino lo espera Cardona, quien recibe una bofetada de Aurora.

Sec. 14. Casa de Fr., quien toca el piano; primer plano de la partitura que deja paso a un escenario onírico. Jardín romántico con parejas que pasean y cantan mientras Fr. deambula como buscando a alguien. Las imágenes del sueño se disuelven y dan paso a la partitura y luego al rostro de Fr.

Sec. 15. Entra la madre y Fr. la convence de que es por ella por quien se interesa d. Matías. Al concluir coge el libreto y tacha sobres sus páginas.

Sec. 16. Casa de d. Matías. Éste discute con F. Llega Cardonay pide alojarse en la casa pues lo han echado de su pensión.

Sec. 17. Calle, noche. Cardona llama a la puerta de la pastelería. Interior. Fr. le comenta cómo va su plan de hacer que d. Matías se interese por su madre. Luego dice que ha convencido a Lambertini para ensayar en el teatro de la Cruz y así no perder de vista a F. ni a Aurora.

Sec. 18. Escenario del teatro de la Cruz. Decorado de una calle por donde varias parejas pasean y cantan el «Coro de la boda». Vestíbulo del teatro. Entra F. y se dirige al camerino de Aurora. Camerino. F. se acerca a la mujer que está sentada ante el espejo y comprueba que es Fr. Ésta le pide que le ayude a desabrocharse el collar. Entra Aurora y los sorprende. Fr. sale y F. va tras ella. Cardona entra e intenta calmar a Aurora; le aconseja que dé celos a F. con otro hombre y deciden que sea Lorenzo. Cuando éste entra, Cardona abandona el camerino y deja a Aurora coqueteando con Lorenzo.

Sec. 19. Escenario. Fr. quien canta dirigiéndose a F., quien la observa desde el patio de butacas; la figura de F. se desdobla y sube al escenario donde ambos cantan a dúo. Al terminar de cantar, desaparece F. y Lambertini felicita a Fr., quien ésta comprueba que un bombero ocupa lugar donde ella veía a $\mathrm{F}$. 
Sec. 20. Floristería. D. Matías compra flores y se entera de que su hijo ha comprado en los últimos días varios ramos.

Sec. 21. Habitación en casa de Fr. Ayuda a su madre (ilusionada ante la visita de d. Matías) a vestirse. Salón: d. Matías espera con un ramo de flores; sale la madre y coquetea con él. Conversación de equívocos en la que la madre cree que d. Matías se le está declarando; cuando descubre que d. Matías pretende a Fr. se desmaya. Sale Fr. y le da aire con un abanico. Acompaña a d. Matías a la puerta y le cuenta que su madre pensaba que iba a pedir la mano de ella para F.; le confiesa que ella odia a F. pero que éste no la deja en paz. D. Matías se va dispuesto a arreglar cuentas con su hijo. Fr., al quedar sola, tacha unas páginas del libreto.

Sec. 22. Casa de d. Matías. F. confiesa a Cardona sus celos hacia Lorenzo. Luego, F. queda solo, fumando y pensativo, mientras suena el tema «Por el humo se sabe donde está el fuego». Llega d. Matías furioso y lo insulta; Cardona acude a los gritos y defiende a F. Situación de equívocos, pues ambos creen que d. Matías se está refiriendo a Aurora. D. Matías se marcha furioso amenazando con que va a solicitar en el Ministerio para F. un destino lejos de España. F. comprende el juego que se trae Fr. y decide jugarlo él también.

Sec. 23. Terraza de un café. Fr. y Cardona comentan la marcha de su plan de acuerdo con el libreto.

Sec. 24. Escaparate de una tienda de disfraces. Las máscaras colocadas en él cobran vida y se lanzan a la calle cantando y bailando. Rodean a una mujer con máscara, y la persiguen, sin dejar de cantar y bailar.

Sec. 25. Salón de baile. Aurora baila con Lorenzo y F. la observa. La mujer de la máscara coquetea desde lejos con F. y lo llama; alguien con disfraz de diablo intenta cogerla en brazos pero ella escapa. Fr. se acerca a F., quien la felicita por su próxima boda con d. Matías y le dice que ha solicitado un destino en el extranjero. Se les unen d. Matías y la madre de Fr. F. les pide que celebren la boda antes de él irse. Aurora desde su mesa mira con odio hacia el grupo.

Sec. 26. Calle. El grupo de F. sube a un coche. Aurora sale seguida de Lorenzo; suben a otro coche y pide al cochero que siga al anterior. La dama del antifaz sale también, perseguida por la persona disfrazada de diablo. Aquella se quita el antifaz y se descubre que es Cardona, quien pide al perseguidor que lo deje en paz; éste se quita a su vez la máscara y resulta ser una mujer voluminosa. Cardona huye.

Sec. 27. Café cantante. F. y su grupo sentados a una mesa; entran Aurora y Lorenzo y se sientan en otra próxima. F. habla aparte con $\mathrm{Fr}$. intentando la reconciliación, pero ella se niega. Llega Cardona, con su atuendo femenino pero sin el antifaz. Aurora, después de mirar insistentemente hacia la mesa de F., se levanta y desafía a los hombres 
presentes a bailar con ella; Lorenzo, a su vez, promete matar a quien lo intente. F. responde al desafío y Fr. intenta detenerlo diciendo que es a d. Matías a quien toca responder; F. no le hace caso y sale a bailar con Aurora mientras Lorenzo se escapa para no luchar. Cardona convence a d. Matías para que saque a bailar a la madre de Fr. Cuando se quedan solos en la mesa, Fr. comenta que las cosas no están ocurriendo conforme al libreto. Aurora, mientras baila,propone a F. hacer las paces. Fr. los mira con tristeza y no para de beber; se va emborrachando.

Sec. 28. Espacio irreal. Fr. observa a F. y Aurora abrazados sobre un escenario y cantando. Fr. huye y se topa con Lambertini que, con gesto diabólico, dirige la orquesta desde el foso. Las máscaras irrumpen y la rodean; Fr. huye; se superponen vertiginosamente primeros planos de las máscaras; Fr. corre por una calle y cae al suelo. F. se acerca.

Sec. 29. Calle «real», ante la puerta del café cantante. F. abraza a Fr., aún en el suelo, y cantan. Se abrazan; llegan d. Matías, la madre y Cardona. D. Matías al verlos abrazados pide explicaciones a F; este le dice que se han querido siempre y le solicita permiso para casarse con Fr. D. Matías termina aceptando y mira compungido a Fr. y F. que se alejan corriendo y se suman a las máscaras.

\subsubsection{Las estrategias metaficcionales}

Si comparamos esta trama con la de la zarzuela original, resumida anteriormente, se observará que Vajda y sus guionistas no han pretendido «ilustrar» dicha zarzuela sino que han hecho vivir a la protagonista una peripecia similar a la protagonista de aquella a la vez que, simultáneamente y a través de sus ensoñaciones, la introducen en el universo de la ficción teatral, en donde vive algunas de las situaciones de la trama original, aunque sin respetar su linealidad cronológica (secuencias $2,14,19,28)^{10}$. En tales secuencias se desarrolla parte de las ilustraciones musicales del filme, mientras que otras se integran en el espacio de la historia «real»" La «Canción del ruiseñor» en el ensayo de Francisquita con el que se abre la película, el posterior ensayo de «El pañolito se le cayó», en el obrador de la pastelería (sec. 9), la canción de «El Marabú» interpretada por Auro-

10. Un carácter onírico tiene, asimismo, la secuencia 24 en donde las máscaras del escaparate cobran vida, aunque en este caso no sea producto de una ensoñación de la protagonista.

11. Los intérpretes principales del filme Mirtha Legrand (Francisquita), Emma Penella (Aurora) y Armando Calvo (Fernando) fueron doblados por profesionales del género lírico: Mimí del Pozo, Lily Bergman y Esteban $\mathrm{G}$. Leoz respectivamente. 
ra sobre el escenario del teatro de la Cruz (sec. 11), el «Coro de la boda» interpretado por los aficionados sobre ese mismo escenario (sec. 18) y la romanza «Por el humo se sabe donde está el fuego» que suena en off mientras Fernando se reconcome de celos en el salón de su casa (sec. 22) ${ }^{12}$.

La zarzuela original no llega, pues, a representarse más que a través de algunos fragmentos desordenados, mientras que la totalidad de su trama, sometida a un grado de manipulación notable, se narra a través de la peripecia de una protagonista, que la utiliza como modelo para desarrollar sus estrategias amorosas. Se establece de ese modo un elaborado juego metaficcional a partir no sólo en la permeabilidad de las fronteras entre el universo de la representación teatral (que el espectador sólo presenciará parcialmente) y el de la «realidad» de la joven protagonista, sino de los comentarios e imágenes que, a lo largo del filme, van puntualizando la dependencia entre la acción de la pieza original y la que protagoniza la Francisquita cinematográfica, quien planifica sus actuaciones de acuerdo con aquélla. Por ejemplo, las ocasiones en que Francisquita consulta el libreto de la zarzuela ${ }^{13}$ o tacha páginas que corresponden a acciones ya vividas (sec. 15 y 21). O los diálogos con Cardona, que actúa como su confidente y ayudante: el que sucede a la escena del pañuelo (sec. 12) en donde consuela a Francisquita diciéndole que la culpa de que las cosas no hayan salido bien es de Fernando, que no se sabe el papel, y a continuación la anima a «hacer escena por escena todo lo que dice el libreto», pues así, «con un poco de suerte podemos tener el mismo resultado final de la obra»; el momento cuando, ante los remordimientos de Francisquita por implicar a su madre en el juego, le responde « $i$ Que lo sientan los autores del libreto!», para posteriormenteenfrascarse en la discusión sobre las estrategias siguientes que propone dicho libreto (sec. 17); el diálogo en que

12. J.L. Téllez se refiere a este respecto a la «función alucinatoria» que desempeña el sonido orquestal ya que las canciones que interpreta la protagonista en «su realidad» tienen un acompañamiento musical mínimo (un piano) o carecen de él, las que suenan en sus ensoñaciones lo hacen con un nutrido acompañamiento sinfónico. La única excepción la constituye la secuencia inicial en la que el sonido orquestal que acompaña a la voz de Francisquita mientras los viandantes se paran embelesados a escucharla, se reduce al de un simple piano cuando la cámara penetra en el interior de la academia de Lambertini. Ello permite a Téllez afirmar que dicha escena de la calle no se sitúa en el plano de la realidad, sino que es una más de las ensoñaciones que experimenta el personaje. «Doña Francisquita (1952)», en J. Pérez Perucha (ed.): Antología crítica del cine español (1906-1995), Madrid: CátedraFilmoteca Española, 1996, pp. 327-330; la referencia en p. 330.

13. Como anota José Luis Téllez (op. cit., p. 329), el libreto mostrado en la pantalla es el de una edición contemporánea al rodaje del filme (1952) y no al estreno de la zarzuela (1923); en todo caso una edición inexistente en el tiempo de la acción cinematográfica que se sitúa, como la de la zarzuela, a finales del siglo $x i x$. 
comenta a Francisquita la obligación que el libreto le impone ahora a él de vestirse de mujer (sec. 23); o el que tiene lugar en la venta, cuando Francisquita, al ver a Fernando bailando con Aurora, se queja de que las cosas no están saliendo de acuerdo con el libreto (sec. 27). Y, especialmente, el diálogo de cierre (sec. 29):

FERNANDO (A DON MATÍAS). -[...] Oye el canto alegre de la juventud que triunfa.

FRANCISQUITA. -Como en el libro.

DON MATÍAS. - ¿De qué libro hablas?

CARDONA. - De este: Doña Francisquita. La juventud triunfa. Finaldel tercer acto.

Todo ese juego metaficcional, de continuas referencias a un texto inexistente en el momento de la acción y que, paradójicamente, sirve como pauta de la misma, significa una continua trasgresión a la verosimilitud del universo fïlmico presentado y contribuye de manera decisiva a aumentar la distancia entre dicho universo y la instancia narradora y a potenciar, de ese modo, la mirada irónica desde la que ésta lo afronta.

Otro elemento que cabe también ser calificado de estrategia metaficcional es el tratamiento antinaturalista de la puesta en escena, que subraya intencionadamente la teatralidad de la historia. Con ello no me refiero sólo a las secuencias de las ensoñaciones de la protagonista (en las que el antinaturalismo estaba exigido por la dimensión onírica, la cual se subraya mediante el barroquismo de los decorados, la intervención orquesta $l^{14} \mathrm{y}$ el uso de una iluminación que resalta la gama de los azules y verdes) sino a todas las que narran las peripecias que tienen lugar en el «mundo real»: dicho mundo es premeditadamente artificioso y sus exteriores recreados en el plató, el tratamiento antirrealista de la iluminación, la interpretación estereotipada de los actores se encargan de sugerir continuamente al espectador el carácter de acción «representada». Podrían citarse como ejemplo de esa puesta en escena antinaturalista la secuencia de apertura, con los personajes deambulando a ritmo de ballet por una plaza innegablemente teatral (pese a la presencia del tranvía de mulas) y extasiándose al oír el canto de Francisquita que les llega desde un balcón; o la secuencia 24 en que las máscaras colocadas en un escaparate cobran vida y persiguen y rodean, sin dejar de danzar, a Cardona disfrazado de mujer.

14. Véase lo apuntado en la nota 11. 


\subsubsection{La degradación a través de los recursos humorísticos}

El uso de las estrategias metaficcionales señaladas que se utilizan como procedimiento de subrayado de la distancia irónica desde la que Vajda y sus guionistas abordan la historia original, se complementa con el tratamiento degradante a que es sometida la misma y mediante el cual el suave humor teñido de sentimentalismo y de nostalgia deja paso a una mirada si no ácida, si bastante ridiculizadora del aquel universo pacato y de la mentalidad pequeño-burguesa de sus habitantes ${ }^{15}$.

Ese tratamiento afecta, por una parte, a algunos de los personajes de la historia que sufren una transformación tendente a dotarlos de una dimensión cómica de la que carecían en la obra de partida; así, Lorenzo, el fiero mozo enamorado de Aurora, se convierte en el representante artístico de la cantante, un cincuentón apocado que se deja utilizar por aquélla para dar celos a Fernando; o Cardona, el confidente de éste último, quien es presentado como un amigo gorrón y poco escrupuloso ${ }^{16}$ que vive a costa suya y que se dedica a confabular con Francisquita para que ésta lleve a cabo sus propósitos. En la misma línea está la incorporación de personajes que no existían en la zarzuela y cuya función es la de refuerzo de la comicidad como ocurre en los casos de Lambertini, el maestro de música de Francisquita o de Pepe, el camarero de la pastelería ${ }^{17}$.

Esa mirada irónica se refuerza con la incorporación de numerosos elementos cómicos, a través de numerosos gags visuales o situacionales y, en menor medida, a través del diálogo. Entre los primeros se pueden citar:

15. En la misma línea ridiculizadora del la pequeña burguesía finisecular se encuentra la película Novio a la vista, que Luis García Berlanga rodó dos años después y en cuyo guión participó también (junto a Berlanga, Bardem y Neville) José Luis Colina, uno de los guionistas de Doña Francisquita. Pienso que estos filmes y otros que se rodarán con posterioridad (recuérdese, por ejemplo Sólo para hombres, filmado por F. Fernán Gómez en 1960, sobre la comedia Sublime decisión, de Miguel Mihura) suponen, por su acidez crítica, un cuestionamiento de la visión complaciente e idealizadora (ligada a unos planeamientos ideológicos obviamente reaccionarios) que el cine español había venido presentando del siglo xix en sus producciones de los años 40 y parte de los 50 .

16. El personaje es una recreación obvia del tipo del «fresco», omnipresente en el teatro de Muñoz Seca y de todos sus epígonos.

17. La elección para estos papeles de actores especializados habitualmente en un registro cómico, contribuyó a potenciar la dimensión irónica de la historia: Antonio Casal interpreta a Cardona,Manolo Morán a Lorenzo, José Isberta Lambertini,Antonio Riquelme a Pepe y Julia Lajos a doña Francisca. El único disonante de ese reparto es Jesús Tordesillas, que encarna a un contenido y escasamente ridículo don Matías. 
-El descubrimiento de la sordera que afecta al viejo pasajero del tranvía, el único que protesta porque el conductor se haya detenido para oír el canto de Francisquita (sec. 1).

-La conversación entre Fernando y Cardona en el club de esgrima, mientras aquél recibe una ducha con una regadera de manos de un sirviente (sec. 7).

-El ensayo de Francisquita con Pepe, el camarero de la pastelería, quien le da las réplicas del diálogo de una manera ausente y mecánica (sec. 9).

- La transformación de Fernando, al que Francisquita piensa estar dirigiendo su canción desde el escenario, en un bombero encargado de la seguridad del teatro (sec. 16).

- La situación de Cardona disfrazado de mujer y perseguido insistentemente por un sujeto con disfraz de diablo, con el final sorpresivo de que cuando él se quita el antifaz para que su perseguidor desista al ver que es un hombre, aquél se revela como una voluminosa y forzuda mujer (sec. 21-23).

Entre los numerosos elementos de comicidad incorporada a través de diálogos que no figuraban en el texto original, podrían citarse el comentario de Lorenzo, al botones al que Aurora acaba de arrojar el ramo de flores: «Has tenido suerte de que no venían en un tiesto» (sec. 5); la escena en que Cardona pide dinero a Fernando para abonar la consumición y evitar así que sea siempre su amigo el que pague (sec. 8); el diálogo en que Cardona, otra vez en su condición de gorrón, intenta convencer a Pepe, el camarero de la pastelería, de que no le debe nada por los dos pasteles que se ha comido (sec. 9); la discusión entre don Matías y su hijo (en el momento en que aquél, al intentar colgar un cuadro se ha machacado un dedo) llena de palabras y expresiones de doble sentido como «pastel», «dar en el clavo», «chuparse el dedo», etc. (sec. 16); la revelación que doña Francisca hace a su hija de cómo se declaró a su difunto marido (sec. 21) y un largo etcétera.

\section{Conclusiones}

Todo lo hasta aquí expuesto permite afirmar que la Doña Francisquita de Ladislao Vajda resulta un ejemplo elocuente de la complejidad de cualquier operación de traslado de un texto literario a la pantalla por la cantidad de factores implicados en ella. Ello obliga a prestar una atención especial al contexto en que las prácticas adaptativas se producen, entendiendo dicho contexto en su sentido más amplio; por eso resulta necesario interrogarse no sólo sobre los condicionamientos técnicos, económicos o ideológicos sino también sobre los que imponen la existencia de unos modelos de producción precedentes, la prevalencia de unas corrientes 
estéticas determinadas o la opción desde la que el realizador aborda el texto literario y que puede oscilar entre la de una «reescritura» creativa del mismo o la ilustración meramente artesanal. Sin olvidarse tampoco de las expectativas con las que el público al que va dirigido se enfrenta a la recepción del filme y que pueden depender, entre otros factores, de su conocimiento o desconocimiento del texto previo, de la inscripción o no del filme dentro de un esquema genérico o de la acción «directriz» que los paratextos anexos (declaraciones de los responsables, críticas, campañas publicitarias, etc.) ejerzan sobre dicho público.

En el filme de Vajda resultan fácilmente perceptibles muchos de tales condicionantes, como he tratado de poner de manifiesto, aunque el propósito que ha guiado mi análisis sea el de destacar la función de los procedimientos distanciadores (estrategias metaficcionales y recursos humorísticos de índole situacional o verbal) que el autor utiliza para subrayar la mirada irónica desde la que se enfrenta al texto de la zarzuela y al universo en él presentado.

Pero esa mirada irónica, y los procedimientos mediante los que se expresa tenían que ser puestos en conexión, aunque fuera de modo somero, con los múltiples y diferentes factores constituyentes del contexto de producción y recepción del filme. Ello me ha llevado a definir la «lectura» propuesta por Vajda como una arriesgada operación rupturista no sólo con relación al género cinematográfico en que se inscribía (la zarzuela cinematográfica) sino además respecto de los criterios estrictamente fidelistas con que el cine español había abordado hasta entonces las adaptaciones de textos literarios y, sobre todo, con relación al modo de narración imperante en los productos de nuestra industria cinematográfica, apegada aún (y todavía por muchos años) a un clasicismo retórico del que tardaría en desprenderse.

El molde genérico, que desde la llegada del sonoro había ido perdiendo capacidad productiva, estaba totalmente anquilosado y, por tanto, en condiciones idóneas para una renovación. Pero la propuesta de Vajda es más rupturista que renovadora, al cuestionar los criterios excesivamente conservadores por los que regía la adaptación de textos literarios a la pantalla y optar por una recreación personal de la historia en vez de mantenerse fiel a la literalidad de la misma. Por otra parte, el cuestionamiento de los mecanismos de la narración cinematográfica clásica mediante el complejo juego metaficcional que pone en práctica, era otro factor que contribuía a subrayar el carácter rupturista de su propuesta ${ }^{18}$. Todo ese conjunto de

18. Dos años después Juan de Orduña, al adaptar la novela de Baroja Zalacaín el aventurero, lleva a cabo un experimento similar, al sustituir la linealidad narrativa del texto por un complejo juego 
trasgresiones hacía del filme de Vajda un producto difícilmente aceptable para el público español del momento, especialmente para aquellos espectadores anclados en un conservadurismo recalcitrante como debían de ser los entusiastas del molde genérico que el director húngaro había violado tan a conciencia. Por ello, la recepción de la Doña Francisquita cinematográfica distó de ser entusiasta, pese a la calificación «de interés nacional» que se le adjudicó ${ }^{19}$.

La opción estética de Vajda es inseparable, por supuesto, de una opción ideológica. El distanciamiento irónico logrado mediante las rupturas descritas y mediante el tratamiento humorístico que se imprime a la historia original es, como señalé más arriba, la expresión de una postura crítica frente al mundo, moralmente pacato e ideológicamente anclado en el más rancio conservadurismo, de la pequeña burguesía española finisecular. Puede suscribirse la afirmación de José Luis Téllez de que mientras la zarzuela de Amadeo Vives es una mirada «ensoñada, ahistórica y autocomplaciente sobre el desaparecido mundo del sainete», el filme que a partir de ella realiza Vajda cabe ser calificado de «fascinada denuncia de semejante dispositivo referencial» con la que el realizador húngaro está proponiendo, en última instancia, una reflexión sobre la condición irreversible del tiempo ${ }^{20}$.

Cabe añadir que esa visión crítica no ha de ser imputada exclusivamente a Vajda (aunque su condición de extranjero recién desembarcado en nuestro país incrementase su percepción extrañada) sino también a los guionistas que con él colaboraron, José Luis Colina y José Santugini. Su mirada lúcida sobre la dura realidad española del momento, junto con la de algunos otros guionistas y directores, contribuyó a abrir en el muro del monolitismo ideológico imperante una primera brecha que se iría agrandando a medida que avanzaba la década y posibilitando un cine diferente, crítico y seriamente comprometido con su entorno.

enunciativo; este tipo de propuestas, inéditas hasta entonces en el cine español, lleva a pensar en que algunos filmes considerados en el momento de su estreno una década antes como revolucionarios (Ciudadano Kane, de Orson Welles, por ejemplo) comenzaban a servir de modelo a nuestros directores y, por consiguiente, a adquirir la categoria de canónicos. Véase al respecto mi trabajo «La novela de Pío Baroja en el cine», Ínsula, noviembre 2006.

19. Vid. J.L. Téllez, op. cit., p. 328. Alude también al desconcierto que produjo la película entre los miembros de la Comisión de Clasificación y Censura de la Dirección General de Cinematografía, uno de los cuales, Juan Esplandiu, mostró su rechazo a la calificación concedida aduciendo que el filme «está plagado de anacronismos, y resulta difícil comprender cuándo lo narrado pertenece a la zarzuela y cuándo a la realidad».

20. Íbidem, p. 330. 